\title{
Curzon's Role in the Development of Technical and University Education in India
}

\author{
Sujata Banerjee* and Sunayana Maiti*
}

(Received 11 May 2018; revised 28 May 2018)

\begin{abstract}
The establishment of engineering colleges in the mid nineteenth century eventually led to the rise of scientific and technical consciousness in the country. These were initially civil engineering colleges created to serve the PWD, where Indians were trained only for the lower subordinate positions while the higher grades were reserved for Europeans. The courses were mainly theoretical in nature with very little emphasis on the practical. Entering the twentieth century the development and propagation of higher technical education accelerated and certain spectacular exceptions developed in the institutionalization of science and technical education. What were the reasons behind such a dramatic change? The answer to this question can be found if one would assess the significance of the policies taken by the colonial government (official policies) and the indigenous/ native efforts towards higher technical education and university education. Therefore, this paper aims at assessing the significant and impactful turning points in the history of two aspects of higher education (technical education and university education) during the early twentieth century with the special emphasis on the role of Lord Curzon.
\end{abstract}

Key words: Lord Curzon, Technical Education, University Education.

\section{Introduction: The Formative Stage in Technical Education}

Following Woods Dispatch (1854) in the nineteenth century, three universities in Calcutta, Madras and Bombay were established and with it came the western education through the University system. However the universities were only examining bodies and research was not in their agenda till the first decade of the twentieth century. Scientific researches were mostly done in the colleges like the Presidency College, St. Xavier's College, and, institutions like Indian Association for the Cultivation of Science (IACS) in Calcutta which testify the practice of science in their laboratories.

The nineteenth century also witnessed the introduction and development of organized/ institutionalized engineering education between 1847 and 1880s. The technical schools existed in Calcutta and Bombay as early as 1825 for the training of artisans and artificers. These industrial schools were attached to ordinance factories and other engineering establishments. The industrial schools established in Guindy (Madras) in 1842 was first attached to the Gun Carriage Factory and the school in Poona in 1854 was set up for the training of overseers (Sen, 1989, pp. 224-248). The first engineering college was established in Roorkee for the training of Civil Engineers, mainly out of the need to form a canal for communication from Bengal to Upper India. The engineering colleges were opened in Bengal, Madras and Bombay. Some of them were: Shibpur Engineering College (1854), Guindy Engineering College (1859) and Poona Engineering College (1865-66).

\footnotetext{
* PhD Scholars, Department of History, University of Calcutta and Research Fellows, The Asiatic Society, 1 Park Street Kolkata, 700016. Email: banerjeesujata23@gmail.com; sunayana.maiti@gmail.com
} 
These colleges were established in pursuance of a government policy, but the pattern of training in these three colleges was theoretical in nature. Later on, these colleges were upgraded to degree level colleges in Civil engineering (Kumar, 2011).

These colleges were created to serve the PWD and the Indians were trained for lower subordinate positions while the higher grades were reserved for Europeans. With time the loopholes in this system came to the forefront. Gradually this led to the introduction of courses in other branches of engineering like Mechanical and Mining.

\section{The Dawn Society and the NCE - Indigenous EfForts towards Science and Technical Education}

The Dawn Society was set up in 1904. The journal of the society The Dawn, became a vehicle for the expression of nationalist concerns, its focus shifted to industrialization and education and specifically to technical education during the period 1904-1907 (Raina, Habib, 2004, p.86). The opening of the Dawn society 1902 by Satish Chandra Mukherjee, was a significant step taken towards the propagation of 'National' education in literary, scientific and technical subjects- this was transformed into the National Council of Education (NCE) in 1906 (Palit, 2011; Bandopadhyay, 2012). Its program of Swadeshi movement led them to provide an alternative path of scientific and technical education. For this purpose along with Bengal National College (BNC) for Science and Arts, Bengal Technical Institute (BTI) launched the first phase of technical education (Gupta ed. 2011, p.118).The story of the practice of science in a colonial world is one of dislocation, redefinition, and integration. In India science made new sense, urged new hypothesis, and produced critiques of the dominant centre by both Europeans and Indians (Chakrabarti, 2004, p.298).

\section{The Role of Curzon in University and Technical Education (1900-1914)}

By the turn of the nineteenth century some awareness is found for a scientific and technical education. However the Education Commission of 1882 was silent on the matters of technical education. When Lord Curzon became the Viceroy at the end of the century, the picture began to change. How Curzon took interest to technical education can always be seen from different perspectives. This section is an attempt towards the same.

\subsection{The Simla Conference}

The Simla education conference held in 1901 was an important turning point in the history of educational reforms in India. Curzon himself chaired the conference and the conference continued for fifteen days. The colonial government under the governorship of Lord Curzon for the very first time took a strong initiative to define technical education which is mentioned as (i) The study of scientific methods and principles underlying the practice of any handicraft, industry or profession; and (ii) The application of those methods and principles to the practice of the handicraft, industry, or profession in question. ${ }^{1}$

The conference further defined the above, by stating that the first is, the primary or technological aspect of the subject, and the second is its subsequent and practical application. The outcome of the deliberation of the Simla Conference of 1901 laid down the general principles to be observed in respect of technical education in India. The principles embodied in the conclusions of the conference regarding industrial schools were: (i) that they should be educational and not commercial institutions; (ii) that in country districts they should be devoted to the study of single indigenous products; that in towns they should deal with manufactures and that several industries might be collected in one building; 
(iii) that only those pupils should be admitted to a school who intend to practice the trade taught there and (iv) that in the provinces where the suggested developments admit of wide or rapid growth, it should be for the consideration of the local governments whether a separate technological department of Government may in time be instituted, for their special supervision and control. ${ }^{2}$

Lord Curzon accepted these conclusions and addressed all local governments in November 1901, urging the importance of developing and organizing industrial schools. ${ }^{3}$

The criticisms against the Simla Conference were: (i) he excluded from the definition that more advanced form of educational activity which involves the application of the most highly trained faculties to scientific experiment, (ii) His Excellency further excluded any steps to be taken towards the revival of native arts and industries, as also the arrangements made for the bifurcation of studies in primary and secondary schools.

It is clear that what Lord Curzon wanted was technical and industrial schools to train up artisans and craftsmen in a proper fashion. But the contemporary newspapers criticized Curzon by saying

\begin{abstract}
Our countrymen are certainly not prepared to accept this very narrow interpretation of the object and scope for technical education for India, unless some definite assurance is given by Government that the question of Scientific Research, as well as that relating to the revival of Native Arts and Industries, will be taken up separately and dealt with in a satisfactory manner.
\end{abstract}

These matters were not discussed properly as very few could speak on the matter with authority. The papers also stated that 'there will be great disappointment throughout the empire if while discussing education these subjects were ignored'. ${ }^{4}$

\subsection{University Reforms/University Act of 1902-1904}

The next important step taken towards the reform of Indian education was the appointment of the Indian Universities Commission in 1902. The two main aims of the Simla Conference were: (i) The expansion and encouragement of knowledge and education and (ii) To build the character of the student.

Curzon admitted that some of the errors of the existing system of education were very much on the surface as it was a slavish imitation of English models, and the colonial government never purged themselves of the taint. For instance, the simple copying of the London University model and introducing it to the Indians was too hasty. Then 'we opined that it was enough to teach English to Indian children before they had even mastered their native tongues. Finally, by making education the sole avenue to employment in the service of State, we unconsciously made examination the sole test of education' (Raleigh, 1906, p. 31).

The principal conflict of Lord Curzon's term in office centred upon his education policy (Fraser, 1904, p.175). Education there was, but it was narrow in its range, exclusive and spasmodic in its application, religious rather than secular, theoretical rather than utilitarian, in character. Above all, it wholly lacked any scientific organization, and it was confined to a single sex. (Raleigh, 1906, pp. 29-30)

Lord Curzon had already made up his mind that the Conference must be followed by a more public inquiry, and on January 27, 1902, the constitution of a Universities Commission was announced. The Commission was appointed to inquire into the conditions and prospects of the Indian universities, to report upon proposals which

\footnotetext{
Ibid., p. 859

IOR, L/PJ/6/798, Report of the Committee on Technical and Industrial Education, Ranchi, 1914, p.1.

4. IOR/ MSS.EUR F.111 249/ Curzon Collection; Extracts from Indian Newspapers Cuttings from - The Tribune, Saturday, September 28, 1901, p.139 Memorandum on the encouragement of indigenous industry in India - Paper on Technical Education Conference 1901
} 
might improve their constitution and working, and to recommend such measures as might tend 'to elevate the standard of University teaching and to promote the advancement of learning'(Fraser, 1904, p.188).

The Commission made a three months' tour, visiting all the universities, and a number of affiliated colleges, and two months afterwards, in June 1902, it presented its report. It examined 156 witnesses, and the issues it had to decide were not recondite. Upon its recommendations the Universities Bill was based (Fraser, 1904, p.189).

The principal reforms advocated by the Commission included a reduction in the size and a change in the constitution of the Senates, steps which were, indeed badly needed. The Senate of Allahabad University numbered 82, Lahore 104, Calcutta 180, Madras 197, while Bombay Senate had actually 810 . The conditions existing in Bombay Senate were extraordinary. The local Government and the university authorities had apparently lost all recollection of the reasons for which the honour of fellowship was instituted. Academic qualifications were not the slightest passport to selection, and sometimes hindrance. There were Fellows so illiterate that they could hardly sign their names (Fraser, 1904, pp.188-190).

Changes in the constitution of the syndicates were also advised. The Commission further recommended that the territorial limits of jurisdiction of universities should be defined, and that no new universities should for the present be created; that stringent conditions for the recognition of affiliated institutions should be imposed; that the universities should conduct no school examinations. It was urged that the minimum age for matriculation should be sixteen. The Commission said that there should be insistence on the better equipment of affiliated colleges, and supervision of places of residence of students. Three recommendations which aroused great hostility were: (1) that a minimum rate of college fees should be fixed; (2) that second-grade colleges (teaching only up to the Intermediate examination of a university) should be gradually abolished; (3) that the system of teaching law by law classes attached to arts colleges should be modified (Fraser, 1904, p.190).

The report of the Commission and the comments of the Government upon it were published in October 1902, and were at once subjected to severe attack. It was contested on the ground that the senates and syndicates would be 'officialised' and that the universities would be 'practically converted into government departments'. The system of examinations was defended, as was to be expected. The suggested raising of college fees was fiercely condemned as likely to throw difficulties in the way of higher education of the poor. Many other objections were offered as the agitation grew, but it was always manifest that the proposed cleansing of the system of controlling the Universities was the bitter pill which did most to create opposition (Fraser, 1904, p.191).

For a whole year the report of the Universities Commission underwent heated discussion in the Press and on the platform. On November 2, 1903, the Universities Bill which had been previously submitted to the Secretary of State, was introduced into the Legislative Council by Sir Thomas Raleigh. The Viceroy himself summarized the principle features of the Bill in the following words:

Its main principle is ... to raise the standard of education all round, and particularly of higher education. What we want to do is to apply better and less fallacious tests that at present exist, to stop the sacrifice of everything in the colleges which constitute our university system to cramming, to bring about better teaching by superior class of teachers, to provide for closer inspection of colleges and institutions which are now left practically alone, to place the Government of the universities in competent, expert, and enthusiastic hands, to reconstitute the senates, to define and regulate the powers of the syndicates, to give statutory recognition to the elected Fellows, who 
are now only appointed on sufferance, ... to show the way by which our universities, which are now merely examining Boards, can ultimately be converted into teaching institutions; in fact, to convert higher education in India into reality instead of a sham. These were the principles underlying the Bill (Fraser, 1904, pp.198-199).

Lord Curzon afterwards commented that 'We provided the machinery for reform; but we leave the universities to carry it out'. The universities were given new governing powers and requested to adopt a policy. That policy has been compendiously defined as intended 'to substitute for a system which compels them also to study those subjects systematically under efficient instruction and supervision'. The reformed senates were to consist of not more than one hundred Fellows, and their tenure of office was in future to be not more than five years; the syndicates were to be remodeled; and the ultimate decision regarding the affiliation and disaffiliation of colleges, and the recognition of schools, was left in the hands of the Government, who would receive the recommendations of the reformed universities (Fraser, 1904, p.194).

Curzon claimed that a very large measure of independence was left to the senates, and that the real power for the future would be vested in them. His ideal was that of 'self-governing institutions watched parentally by the Government in the background' (Fraser, 1904, p. 199).

\section{Conclusion}

The Simla Conference and the University Act provided the base for further development and introduction of higher technical and university education in the country. Lord Curzon played a pioneering role in creating research based Universities. Therefore in this regard we cannot deny the part played by Lord Curzon's administration. The intention was directly related to the colonial empire building on a higher plane and also to the benefit of India on a more related and sub divisional plane.
But, in saying this, the indigenous efforts (Sarkar, 2012) towards the propagation of technical education in the twentieth century should not be ignored. In this paper therefore, we have tried to look at Curzon from an innovators point of view. We have tried to assess his policies by trying to judge its effects and its newness during the contemporary time and the period to follow.

\section{BibliogRAPHY}

Bandopadhyay, Arun. Technological Education in a Colonial Context: Bengal Engineering College in late nineteenth century India, (Mimeo) Forum for South Asian Studies, Uppsala University, November 2012.

Basu, Aparna. Essays in the History of Indian Education, Concept Publishing Company, New Delhi, 1982.

Chakrabarti, Pratik. Western Science in Modem India: Metropolitan Methods, Colonial Practices, Permanent Black, New Delhi, 2004.

Fraser, Lovat. India under Lord Curzon, William Heinmann, London, 1904.

Gupta, Uma Das (ed.), Science and Modern India: An Institutional History c. 1784-1947 (Delhi, 2011), p.xlvi. The volume is part of History of Science, Philosophy and Culture in Indian Civilization, Vol.15, Part I (General Editor: D.P. Chattopadhyay).

Kumar, Arun. Thomason College of Engineering, Roorkee, 1847-1947 in Uma Dasgupta (ed) Science and Modern India: An Institutional History c. 1784-1947, Delhi, 2011.

Palit, Chittabrata. The National Council of Education and its Progeny: The College of Engineering and Technology, 1906-47 in Uma Dasgupta (ed) Science and Modern India:An Institutional History c.17841947, Delhi, 2011.

Raina, Dhruv and Habib, S Irfan. Domesticating Modern Science: A Social History of Science and Culture in Colonial India, Tulika Books, New Delhi, 2004.

Raleigh, Thomas. Lord Curzon in India, Vol. 2, Macmillan and Co. Limited, London, 1906.

Sarkar, Suvobrata, The Quest for Technical Knowledge: Bengal in the Nineteenth Century, Manohar Publishers and Distributors, New Delhi, 2012.

Sen, Biman. Development of Technical Education in India a State Policy: A Historical perspective, Indian Journal of History of Science, 24.4 (1989):224-248. 